\title{
Pacifism, Supreme Emergency, and Moral Tragedy
}

\author{
Nicholas Parkin
}

\begin{abstract}
This paper develops and defends a new way for pacifists to deal with the problem of supreme emergency. In it I argue that a supreme emergency in which some disaster can only be prevented by modern war is a morally tragic situation. This means that a leader faced with a supreme emergency acts unjustifiably in both allowing something terrible to occur, as well as in waging war to prevent it. I also argue that we may have cause to excuse from wrongdoing the agents who must choose an unjustified action in a supreme emergency.
\end{abstract}

Keywords: pacifism; supreme emergency; moral tragedy; innocence; excuses; war

\section{Introduction}

Anti-war pacifism, broadly speaking, rejects war as an acceptable means for obtaining peace. It is a commitment to peace and opposition to war. The sort of anti-war pacifist argument I have in mind is non-absolute; it holds that modern war ${ }^{1}$ very commonly, or perhaps even inevitably, involves harm to innocent persons on a scale that is too great to be justified. It posits that if the means necessary to waging modern war cannot be justified, then modern war cannot be justified. It holds the antecedent to be true (based on large-scale harm to innocents), the deduction to be valid, and thus the consequent to be similarly true. ${ }^{2}$

The most compelling and common objection to an anti-war pacifist stance is that while war is most certainly harmful, and should be avoided where possible, it can nevertheless be justified when it is the only means of preventing some much greater harm. This is the argument from prevention: as bad as war is, it may sometimes be justifiably fought to prevent some even worse disaster from occurring, such as that which threat-

\footnotetext{
${ }^{1}$ Modern war refers to war fought from the late nineteenth century into (at least) the near future. Particular features of modern war include types of weapons used, typical size of conflicts, locations of conflict, an increased presence of irregular forces, high rates of civilian death, and so on.

${ }^{2}$ See Robert L. Holmes, On War and Morality (Princeton: Princeton University Press, 1989).

(C) Copyright 2014 by Social Theory and Practice, Vol. 40, No. 4 (October 2014): 631-648. DOI: $10.5840 /$ soctheorpract 201440437
} 
ens a political community in a supreme emergency. This challenge basically rests on the claim that large-scale killing of innocents is not allthings-considered wrong, but is, rather, merely prima facie wrong. If so, the moral presumption against killing the innocent may be compromised or overridden by other moral imperatives, such as the duty to prevent innocents from being killed.

The aim of this paper is to propose and defend what might be termed the moral tragedy solution to the argument from prevention. It frames supreme emergencies as morally tragic situations, in which there is no justifiable path to take. While waging war to prevent some great disaster cannot be justified, neither can failing to prevent that great disaster; the first part of the paper is aimed at establishing this position. Moreover, if there is no justifiable course of action to take, then agents who must decide on a course of action nonetheless - the leaders of political communities - might be excused from blame for doing so; the second part of the paper is dedicated to this idea. The third part of the paper examines some of the implications of the preceding discussion.

Put simply, modern war causes great harm to innocents. The term innocent here means "not unjustly harming," or "not unjustly threatening to harm." A rights-based approach to innocence treats it as a right not to be harmed; generally speaking, someone who harms another acts unjustly since she violates that right. One who is not unjustly harming another maintains one's innocence as well as one's right not to be harmed. The innocent are those who are not intentionally or foreseeably threatening another with harm or death; it is at least prima facie wrong to kill them. ${ }^{4}$

Who is innocent in war? Most noncombatants are clearly innocent in the relevant sense, since they do not threaten harm to other innocents. Just combatants may be morally innocent since they are not engaged in any unjust harming, but rather in self- and other-defense. ${ }^{5}$ Approximately 87 million people were killed by war in the twentieth century alone (not including those killed by genocide and famine): 33 million soldiers and 54 million civilians. ${ }^{6}$ The majority of the latter, and perhaps many of the

\footnotetext{
${ }^{3}$ See Judith Jarvis Thomson, The Realm of Rights (Cambridge, Mass.: Harvard University Press, 1990), and Suzanne Uniacke, Permissible Killing: The Self-Defence Justification of Homicide (Cambridge: Cambridge University Press, 1994). From here on, the term "harm" also refers to "threatening to harm."

${ }^{4}$ See Thomson, The Realm of Rights, Uniacke, Permissible Killing, and David Rodin, War and Self-Defense (Oxford: Clarendon Press, 2002).

${ }^{5}$ See Jeff McMahan, Killing in War (Oxford: Clarendon Press, 2009), and C.A.J. Coady, Morality and Political Violence (Cambridge: Cambridge University Press, 2008), pp. 111-12. Combatants are distinguished from noncombatants by distinguishing those who are involved in the chain of agency that prosecutes a war from those who are not. Most civilians are noncombatants, and most soldiers are combatants.

${ }^{6}$ Zbigniew Brzezinski, Out of Control: Global Turmoil on the Eve of the Twenty-First
} 
former, were innocent of any wrongdoing that would compromise their right not to be killed. And the situation has worsened, not improved: from the beginning to the end of the twentieth century, the ratio of military to civilian casualties in war went from $8: 1$ to $1: 8 .^{7}$

\section{Supreme Emergency}

Just war theorists maintain that the evils of war can sometimes be justified if war can be fought to prevent some greater evil; hence the moral presumption against killing innocents may on occasion be justifiably outweighed by the duty to prevent innocents from being killed. ${ }^{8}$

Supreme emergencies in which the killing of many innocents can only be prevented by killing many innocents present the strongest challenge to the claim that war cannot be justified. Note that while the supreme emergency problem faced by the just war theorist focuses on whether some great evil may be permissibly prevented by breaking the rules of war, such as the prohibition on intentionally killing innocents, for the pacifist the extreme measure is modern war itself.

To be a supreme emergency, as Michael Walzer suggests, a threat must be imminent, extreme, and "of an unusual and horrifying kind." Not just that, it must threaten the goods that are essential for the functioning and well-being of the community, in such a way that challenges the very heart of the moral precepts that make pacifists condemn war or just war theorists prescribe the jus in bello. Proof of a real and imminent threat of large-scale massacre and enslavement would constitute a supreme emergency. Supreme emergencies are therefore not just rare, but exceptionally rare, and constitute a horrific outcome should the threatened harm actually occur. It must also be preventable only by actions that fall outside the normal realms of moral acceptability-for the just war tradition, that means breaking the moral rules of war; for the pacifist, that means war itself.

Walzer's solution to the supreme emergency problem is that we may sometimes do wrong to do right, so to speak; we must sometimes get our hands dirty in the name of good to prevent some great evil that it is reasonable to think could not be prevented otherwise. ${ }^{10}$ It is not my task to

Century (New York: Scribner, 1993), pp. 8-10 (does not include deaths after 1993).

${ }^{7}$ Mary Kaldor, New and Old Wars: Organized Violence in a Global Era (Cambridge: Polity Press, 2001), p. 8. Coady has the ratio going from 9:1 to 1:9 (Morality and Political Violence, p. 121).

${ }^{8}$ I leave aside other considerations such as the doctrine of double effect.

${ }^{9}$ Michael Walzer, Just and Unjust Wars (New York: Basic Books, 1977), pp. 252, 253.

${ }^{10}$ See ibid., pp. 251-68. 
discuss Walzer's solution here, except to note that it has encountered both support and rejection in the just war tradition. Some of those who reject it hold it to be paradoxical, given Walzer's commitment to jus in bello principles and the separation of jus ad bellum and jus in bello. Others argue simply that the most important facets of the jus in bello, such as the principle of discrimination (between combatant and noncombatant), ought not be violated, no matter what.

Other possible theoretical answers to the supreme emergency problem include: maintaining a significant moral distinction between killing and letting die, thus precluding the possibility of justified war; ${ }^{11}$ employing consequentialist reasoning to argue that war may be justifiably waged when doing so is the only means of preventing some greater evil; or invoking threshold deontology to maintain that while moral norms take precedence up to a point, beyond that point is the moral realm of consequences, meaning that war may be justifiably waged when doing so is the only means of preventing some greater evil. ${ }^{12}$ The dirty hands, consequentialist, and threshold deontological approaches are all incompatible with anti-war pacifism. Maintaining a significant moral distinction between killing and letting die is compatible with anti-war pacifism, but attempts to maintain such a distinction do not succeed. ${ }^{13} \mathrm{I}$ wish, then, to propose another approach to supreme emergencies, which treats them as tragic moral dilemmas, or moral tragedies. This approach, I believe, is compatible with an anti-war pacifist stance.

\section{Moral Tragedy}

A moral tragedy is a type of moral dilemma, which arises when the moral weight of rights or norms cannot be commensurated with the moral force of consequences or other competing moral considerations, a probably inevitable upshot of ascribing at least some value to most moral systems. In such situations there may be no "right" decision to make. ${ }^{14}$ We may feel that the benefits arising from a certain action will outweigh its costs, but still think that we ought not perform that action; we may be required to perform (or not perform) each of two acts, but are unable to perform

\footnotetext{
${ }^{11}$ See Holmes, On War and Morality, and Jeffrie G. Murphy, "The Killing of the Innocent," The Monist 57 (1973): 527-50. Attempts to establish such a distinction have proved unconvincing: see James Rachels, "Active and Passive Euthanasia," The New England Journal of Medicine 292 (1975): 78-80.

${ }^{12}$ See Michael S. Moore, "Torture and the Balance of Evils," Israel Law Review 23 (1989): 280-344.

${ }^{13}$ Nicholas Parkin, "Pacifism and Supreme Emergencies," unpublished ms.

${ }^{14}$ Some, of course, refuse to accept the existence of moral dilemmas; here I assume their plausibility.
} 
(or not perform) both. When there is no right decision to make, and the available options are tragic, a moral dilemma becomes a moral tragedy.

Bernard Williams argues that if an agent ought to perform two actions, but cannot perform both, it does not necessarily follow from one action being more morally weighty than another that an agent is therefore justified in performing that action; she ought, rather, to do two things. ${ }^{15}$ In tragic cases, an agent might rightly think that whatever she does will be wrong, since neither conflicting moral claim outweighs the other (this is not the same as saying that the actions are equally bad, but rather that neither is good enough to be the right thing to do). ${ }^{16}$

Now one might respond to the moral tragedy picture by asserting that there is always a preferable option. But this alone does not show that the preferable option is justified. That one option consists of a "less bad" action, or produces less bad consequences, than another is not sufficient to justify it. Note, moreover, that this approach does not differ from our standard approach to morality. The moral status of a particular action often does not change depending on the moral status of other actions.

Analogously, any particular legal system distinguishes between legal and illegal actions. Say one must choose between two illegal actions. If one of those actions consists of a worse crime than the other, it does not follow that one may now legally perform the other. The same often seems true of morality, at least regarding sets of particularly bad acts. So even if we perform a terrible action because it is preferable to another, it does not follow that we are justified in doing so, since "we still choose an evil, and in this sense we do something wrong." ${ }^{17}$ In this sense, if all the options involve serious wrongdoing, as Martha Nussbaum argues, "there is no 'right answer'."18 The fact that I am taller than my sister does not in itself show that I am tall; similarly, the fact that one terrible course of action is preferable to another does not justify it.

\section{Supreme Emergencies as Moral Tragedies}

In what way, then, is a supreme emergency a moral tragedy? To begin with, it is difficult to conceive of anything more morally tragic than a

\footnotetext{
${ }^{15}$ Bernard Williams, Moral Luck: Philosophical Papers 1973-1980 (Cambridge: Cambridge University Press, 1981), pp. 73-74.

${ }^{16}$ See Thomas Nagel, "War and Massacre," Philosophy \& Public Affairs 1 (1972): 123-44.

${ }^{17}$ Christopher W. Gowans, Innocence Lost: An Examination of Inescapable Moral Wrongdoing (Oxford: Oxford University Press, 1994), p. 88.

${ }^{18}$ Martha C. Nussbaum, "The Costs of Tragedy: Some Moral Limits of Cost-Benefit Analysis," The Journal of Legal Studies 29 (2000): 1005-36, p. 1007.
} 
situation in which many innocents will be killed no matter what happens. The supreme emergency can be viewed as a moral dilemma because it forces a leader to choose between competing alternatives - one motivated by norms, the other by consequences - that do not outweigh one another. It can be viewed as a moral tragedy since all alternatives are undeniably tragic. On the one hand, the disaster threatened by the supreme emergency must be prevented since it would be so very bad were it to occur. On the other, the supreme emergency must not be prevented because of the extremity of what must be done to prevent it. Both views, it seems, can be rationally defended.

The moral tragedy approach does a good job of describing the dilemma faced by a leader in a supreme emergency. According to this approach, the supreme emergency means there is no way the leader can elect to do what is morally right; she can only choose from morally unjustified options. In this sense, then, the leader has no choice but to do what is morally wrong.

Uwe Steinhoff, however, argues that "one always has a choice. Instead of killing [to prevent a disaster], one can also let the enormous disaster happen." 19 The salient point here, however, is not that the leader cannot choose between waging and not waging war (it is clear that she can), but rather that she cannot make a good choice, a justifiable choice, since the situation forces her to choose a highly unacceptable action. She must act under extremely high levels of coercion; she is unable to choose a justified action. It is in this sense that she has no choice.

In certain situations, there may only be two options - to submit or to fight. And if submission to some intolerable evil is morally unthinkable, people can then intelligibly say that they have no feasible choice but to fight. But this cuts both ways, for one can legitimately and coherently say that if what must be done to fight is morally unthinkable, then one has no feasible choice but not to fight. ${ }^{20}$ Both claims - that we have no feasible choice but to avoid the evils of war, and that we have no feasible choice but to wage war to avoid the evils that will occur if we do notare morally compelling. Hence the supreme emergency that can only be avoided by large-scale warfare is morally tragic.

Brian Orend also states that "supreme emergencies ...[are] cases of moral tragedy. A moral tragedy occurs when, all things considered, every viable option one is confronted with involves a serious moral viola-

\footnotetext{
${ }^{19}$ Uwe Steinhoff, On the Ethics of War and Terrorism (Oxford: Oxford University Press, 2007), p. 144.

${ }^{20}$ Richard Norman, Ethics, Killing and War (Cambridge: Cambridge University Press, 1995), pp. 221-22.
} 
tion." ${ }^{21}$ The fact that morally tragic situations invariably involve serious moral violations means that no matter what one does in a moral tragedy, one cannot justifiably do it: "It is a moral blind alley: there is no way to turn and still be morally justified." ${ }^{22}$ This approach captures not only the difficult dilemma presented by a supreme emergency, but also the "fullblown tragedy" of the situation. It incorporates the idea that killing many innocents is impermissible even if doing so saves many others, for "if you do wrong, you do wrong, even under the pressure of supreme emergency." 23

One might be tempted to think that the moral tragedy simply arises due to different subjective moral claims, where one action appears better to one person and worse to another. In fact, however, the moral dilemma surfaces due to a clash between competing moral imperatives with competing objective strengths. An agent's decision in a moral dilemma will most likely be, in a sense, a personal one, but it is in another sense an objective one in that it invites endorsement or rejection from others as a judgment of the relative importance of particular features of our lives. The claim that war cannot be justified due to the predictable large-scale killing of innocents is an objectively strong one, but so too is the argument that sometimes a threat might be so overwhelming and evil that war must be fought to prevent it, as Norman eloquently suggests:

To go to war is a terrible thing, and that assertion is not just an expression of subjective feeling but a judgement rooted in our understanding of our shared human life. There appear to be situations where war is the only available means of resisting an intolerable evil, and that too is an objective judgement, not a mere expression of feeling. ${ }^{24}$

These competing considerations are characterized by the weight they place on different moral concerns. For some, the maxim "do not kill the innocent," especially in such large numbers, motivates the position against war. For others, consequences matter most, if the killing of a number of innocents in war could prevent the deaths of a much larger number of innocents if the supreme emergency is allowed to occur. But that is not to say that either position neglects the reasoning of the other-the moral tragedy arises precisely because each position is objectively compelling.

\footnotetext{
${ }^{21}$ Brian Orend, "Just and Lawful Conduct in War: Reflections on Michael Walzer," Law and Philosophy 20 (2001): 1-30, p. 28. Orend focuses on the intentional killing of innocents, thus addressing possible violations of the just war theory's jus in bello mentioned above. The point is essentially the same: the choice is between two severe moral violations.

${ }^{22}$ Brian Orend, "Is There a Supreme Emergency Exemption?" in Mark Evans (ed.), Just War Theory: A Reappraisal (Edinburgh: Edinburgh University Press, 2005), chap. 7, p. 148.

${ }^{23}$ Ibid., p. 149.

${ }^{24}$ Norman, Ethics, Killing and War, pp. 222-23.
} 
Walzer has argued that the threat of Nazi Germany to Britain in the early 1940s constituted a supreme emergency. ${ }^{25}$ In 1940, Germany had defeated large parts of Western and Central Europe, had plans to invade Britain, and had already started bombing British cities. Neither the USA nor the USSR had yet entered the war. Winston Churchill first used the term "supreme emergency" to describe this situation, which lasted at least until late 1941, or possibly until sometime in 1943, by which time the USA and the USSR were fighting against Germany and the war had swung in the Allies' favor.

Now Churchill's argument that the situation meant Britain had a right, even a duty, to put aside the rules of jus in bello and purposefully attack innocent German civilians in order to ward off the threat is incorrect, because of the extreme violation of those civilians' rights not to be harmed. But nor could he simply stand by and allow Nazi Germany to invade Britain, and perhaps even more of Europe, with all that that would entail. And so Churchill faced a moral dilemma over that period of time, and could do no right no matter what path of action he decided to take.

\section{Excusing the Agents of War}

I have so far argued that if a supreme emergency that can only be avoided by war is indeed a moral tragedy, then the act of waging war to prevent that supreme emergency cannot be justified. An agent who chooses to so act, therefore, acts unjustifiably. But an agent also acts unjustifiably if she fails to prevent the disaster; whatever the agent does, she does wrong. How, then, to judge leaders' actions as responsible agents in supreme emergencies? How may a pacifist come to terms with the decisions made by leaders in supreme emergencies? In what follows, I argue that they may be excused from blame for what they do, since they must do wrong and thus have no choice but to do wrong. There has been some discussion regarding excusing deluded or coerced combatants from wrongdoing, but very little regarding the possibility of excusing leaders who do wrong by waging or not waging war in the first place. ${ }^{26}$ The pacifist position can be strengthened by maintaining the unjustifiability of modern war, even when fought to prevent some disaster, while recognizing that on occasion it may also be wrong to fail to wage war to prevent some disaster, as well as recognizing the difficulties faced by those who must choose between two or more morally unjustifiable options in a supreme emergency.

\footnotetext{
${ }^{25}$ Walzer, Just and Unjust Wars, chap. 16.

${ }^{26}$ For a brief discussion, see Orend, "Is There a Supreme Emergency Exemption?"
} 


\section{Justifications and Excuses}

An examination of the distinction between the concepts of justification and excuse will lay a foundation to separate the moral assessment of agents from the actions of those agents in morally tragic cases. Justifications apply to the morality of actions; excuses apply to the responsibility of agents for their actions. A justification involves a morally justified action caused by a moral agent (the action is held to be good, and responsibility is accepted), while an excuse involves a morally unjustified action caused by an agent who is, morally speaking, either partly or wholly not responsible for that action (the action is admitted to be wrong, but responsibility is denied) ${ }^{27}$ Simply, we may (or should) perform justified actions, and avoid those from which we must seek to be excused from blame. ${ }^{28}$ Consequently, this distinction has both moral and practical implications. Excused agents have done something wrong; agents who act justifiably have not. When someone is spared negative judgment or punishment, it makes a moral difference whether it is because she was entitled to do what she did, or because even though she acted badly she had an excuse for doing so. ${ }^{29}$

This difference has arisen in cases in which an abusive spouse or partner has been killed. The standard legal defense for such an act is temporary insanity or diminished responsibility. But even though a defendant may be excused, and thus escape punishment, this defense implies that her actions were wrong. Conversely, some have on occasion been successfully defended as having acted in justified self-defense. ${ }^{30}$ One who is excused from blame for wrongfully killing her partner is viewed differently - by others as well as herself - from one who is found to have justifiably acted in self-defense. It appears to matter both morally and practically whether an agent is excused from responsibility for a wrongful act or found to have acted justifiably in the first place.

This difference continues into the international arena-justifying war fought to prevent some disaster is distinct from morally prohibiting war fought to prevent some disaster while perhaps excusing responsible agents from blame for their wrongdoing. The former approach admits that war can be justifiably waged to prevent a disaster; the latter does not. Similarly, the responsible agents are viewed differently-if war is justi-

\footnotetext{
${ }^{27}$ J.L. Austin, “A Plea for Excuses: The Presidential Address," Proceedings of the Aristotelian Society, New Series 57 (1956): 1-30, p. 2. See also Kent Greenawalt, "Distinguishing Justifications from Excuses," Law and Contemporary Problems 49 (1986): 89-108.

${ }^{28}$ Greenawalt, "Distinguishing Justifications from Excuses," p. 91.

${ }^{29}$ Andrew Botterell, "A Primer on the Distinction between Justification and Excuse," Philosophy Compass 4 (2009): 172-96, p. 181.

${ }^{30}$ Ibid., p. 177.
} 
fied, then they have done no wrong, but if it is not, then they have acted wrongly even if they are excused from blame for doing so. Even if the agent of war is excused from blame, however, the pacifist position remains intact so long as the large-scale killing of innocents in modern war is unjustified. This position creates a much stronger presumption against the justification of war than one that even on rare occasions justifies war, just as there is a stronger presumption against killing abusive partners if the only defense available is diminished capacity as opposed to justified self-defense. Excusing the agent does not affect the moral status of the act; it is, rather, an acknowledgment of that agent's particular position.

Let us now turn to the question of when agents may be excused from blame for their impermissible actions. An agent might be excused when her action is motivated by a reasonable yet mistaken belief-a leader might either be excused for waging war to prevent some disaster, or allowing that disaster to occur by refusing to wage war, if she is nonculpably mistaken about the nature of the emergency. An agent might also be excused when necessity, or lack of options, essentially forces her into performing some action - a leader might be excused when she cannot choose a justifiable course of action, due to the fact that none of the possible actions is morally permissible.

\section{Agents Motivated by Reasonable Yet Mistaken Beliefs}

An agent might erroneously believe her action to be justified when it is not, based on a reasonable yet mistaken belief. Indeed, the action may be subjectively justified; a justified act need not always be objectively justified. But, in the strongest sense, a justified act is justified according to some objective standard. So a reasonable mistake can either be subjectively justified or objectively excused, depending on the perspective of the evaluation. ${ }^{31}$ Hence we may distinguish between objectively justified and reasonably subjectively justified (yet objectively unjustified) actions.

The presence of a reasonable yet mistaken belief may exculpate an agent. Recall that we are considering complex situations in which there is no good course of action to take. As such, we can disagree with an agent's beliefs or priorities, or with what she accepts as reasonable harm or risk. But if we accept that there are moral situations in which reasonable people can disagree, and that the agent's evaluation is honest and reasonable, then we might think that the agent is not responsible or not fully responsible for acting wrongly. So what does the justifying is not the belief, but rather the reasonableness of the belief, even if the facts

\footnotetext{
${ }^{31}$ Uniacke, Permissible Killing, pp. 15-17.
} 
differ from the belief. To act reasonably is not just to make sure that we try our best to be aware of relevant facts, but also that we properly balance our interests with those of others. ${ }^{32}$ Therefore we ought to try to be properly informed and to act fairly based on that information; the act should be necessary, proportionate, and so on. The belief must be reasonable; so must the response to that belief.

It is at least plausible that agent-perspectival justification can serve as an excusing condition. But can reasonable yet mistaken beliefs be used to excuse leaders of states from wrongdoing for unjustifiably waging war? Leaders make mistakes - some seem reasonable, some do not. A leader might receive incorrect information that appears reliable, motivating her to act in some way. To be excused, a leader must be mistaken in thinking that her actions are justified, and she must have worked hard to determine whether her beliefs are the correct ones, as well as whether her actions are appropriate and justified responses to those beliefs.

Let us assume that in 2002 and 2003 the leaders of the United States believed that Iraq both possessed and had plans to manufacture weapons of mass destruction. As it turned out, much of this belief was based on bad information. Perhaps, then, their subsequent actions were motivated by subjective error. However, in order for their actions to be excused (assuming that they acted unjustifiably), the subsequent invasion of Iraq would have to be an appropriate response to that information (it would have to be proportionate, necessary, and so on), and they should have attempted to acquire more information so long as they had time to do so. These criteria were not satisfied, not least since the United Nations weapons inspectors had not finished their inspections, had requested more time to do so, and had advised that Iraq was cooperating with inspections and that the confirmation of disarmament through inspections could be achieved in a short period of time if Iraq remained cooperative. Hence the responsible leaders should not be excused from blame for their actions, since they did not act appropriately based on their mistaken beliefs.

If the actions required to prevent a supreme emergency involve killing many innocents, the leaders of a state should be quite sure, within reason, that they are doing the right thing. If it could be shown that their beliefs that led to many innocent deaths were reasonable, then they may be excused from blame for their actions. Leaders of states have far greater access to information than common individuals do. This, combined with the fact that the defense of a state involves a much greater level of destruction than the defense of an individual, might mean that the leaders of a state should be much surer of what they know and what

\footnotetext{
${ }^{32}$ Note that the latter is an objective matter-no excuse can rest on a flawed or overly subjective moral system.
} 
the appropriate response is before they wage war than individuals should be before they engage in violent self- or other-defense.

On the other hand, the leaders of a state may face significant time pressure when having to decide whether to respond to an emergency, as well as the pressure of having to make a complex decision upon which the lives of many innocents may depend. A leader might make the wrong choice even if she has attempted to acquire as much information as possible. Predicting the consequences of each decision might also prove difficult. A leader's mistaken belief could concern either the imminence or the scale of the threat - that, for example, a threat was a supreme emergency when it was not. While leaders ought to know more than common individuals - not just because they have greater access to information, but also because the consequences of war are so much worse than individual self-defense - the situations they face are much more complicated than those faced by common individuals. This increases the likelihood of justified mistaken belief. We may excuse leaders from wrongdoing that is motivated by genuine mistaken belief, but we should also hold them to high standards, especially since the consequences of their decisions can be grave.

\section{Agents Who Have No Choice But to Act}

The second (and more pertinent) way by which an agent may be excused arises when she cannot choose a justifiable course of action. In other words, morally speaking, she has no feasible choice but to do wrong. An agent faced with a morally tragic situation can choose between unjustifiable options, but she cannot choose to not choose, so to speak, nor can she choose to perform a justifiable action. It is in this sense that she has no choice. A leader in a supreme emergency, I have argued, has a choice to wage or not to wage war, but she does not have a choice whether or not to make that decision. She must choose, and if all available options are unjustified, then she has no choice but to choose an unjustified action. Hence one may argue that she ought not to be blamed for her unjustified action, since she cannot perform a justified one (note that if a moral tragedy is to be excused, the plight must not be of the agent's own making).

As I have stated, in a moral tragedy there is no moral concern that can be justified by virtue of being less wrong than the other options available, since all of the options are so significantly and objectively wrong in themselves that they are unjustifiable. One action may seem worse than the other (it may result in a greater number of innocent deaths), but this does not in itself show that action to be justified, since both options are so very bad. I noted above that just as one can claim that one has no fea- 
sible choice but to fight, due to what will happen if one fails to do so, so too can one argue that one has no feasible choice but not to fight, due to the terrible nature of war. A leader may have no choice but to choose to kill many innocents or to let many innocents be killed, and if neither option is morally justified, then she is forced, by virtue of the role she fills as leader, to choose to act unjustifiably.

Note that if I must choose wrong no matter what I do, I should try to minimize the harm caused by my actions. Doing so does not necessarily mean that my choice is justified, since it may be that neither option is justifiable. Nevertheless, two options can both be unjustified and yet still not equal in terms of impact. But it remains the case that a possible action can be so bad that it cannot be justified solely by virtue of being better, or less harmful, in whatever sense, than another possible action. I would suggest that modern war has historically been so harmful that it is likely to be the worse option, especially given advances and successes in nonviolent conflict resolution and the like. ${ }^{33}$ The presumption should be against war, for all the good reasons established by the pacifist and just war traditions.

Even if a leader must choose between the killing of innocent citizens from her own country and the deaths of innocents from another country, it is not clear that she should prioritize her citizens. In favor of waging war it might be said that necessity dictates that she kill the innocents from the other community. But there are also strong moral reasons for her to avoid killing that group of innocents. Importantly, it does not follow that she should let the innocents from her community die, but rather that she should not perform either action. Neither moral imperative appears to morally trump the other, unless, for example, we think that a leader has a very strong additional duty to protect her community, which binds her to save them. But even if she has such a duty, it is surely not an all-trumping duty; she also has a (very strong) duty not to kill innocents from other communities. The leader, then, is faced with a situation in which she can do no right. If she wages war, she kills many innocents. And if she does not wage war, she fails to do what she has been elected to do, to not only protect and provide for her own populous, but also to protect and provide for the international community.

It is generally accepted that "ought implies can"-an agent can only be reasonably expected to act in a certain way if it is possible for her to do so. There are two ways this might play out in terms of a moral tragedy. First, agent A may not be able to $x$. If A cannot $x$, then it makes little sense to say that A should $x$. If we cannot coherently say that A should $x$,

\footnotetext{
${ }^{33}$ See, e.g., Erica Chenoweth and Maria J. Stephan, Why Civil Resistance Works: The Strategic Logic of Nonviolent Conflict (New York: Columbia University Press, 2011).
} 
then we cannot coherently say that A does something wrong by not $x$ ing. Second, agent B may have to either $y$ or $z$. Now it makes sense to say that B can choose between $y$-ing and $z$-ing. But if neither $y$ nor $z$ can be justified by virtue of being less wrong than the other, then it is true that $\mathrm{B}$ should not $y$, and that $\mathrm{B}$ should not $z$. And if $\mathrm{B}$ has no choice but to do either $y$ or $z$, we can coherently say that B does something wrong by $y$-ing or $z$-ing, but not that $\mathrm{B}$ is bad for having done so, since $\mathrm{B}$ could not have done otherwise. It is for this reason that we might want to condemn the leader's action, but (at least partially) absolve her from blame for performing that action. She could not have done otherwise, so we cannot coherently say that she should have done otherwise.

We might feel that although the leader may be excused from blame, she should also feel remorseful for performing one of the unjustifiable actions. This is because not only has she performed a highly unacceptable action, but also she became the leader because she wanted that job. It is no easy task to become the leader of a state; it requires both effort and conscious choice. But even though she has chosen her role, the fact that genuine moral tragedies are rare in the international arena, as well as the fact that once she had decided to take the position of leader she was forced into the particular situation, suggest that she might nevertheless be excused from blame for choosing either option in the supreme emergency. Igor Primoratz notes that leaders can calmly weigh up the pros and cons of potential actions, and are not "filled with terror," as perhaps an excused individual might be. ${ }^{34}$ This is true, but decisions must be made relatively quickly in a supreme emergency, with substantial pressure, and the consequences of each action are so extremely bad that the moral tragedy remains, even if the decision-making process is slower and calmer than in an individual's own supreme emergency.

This approach to the supreme emergency problem provides a good moral description of a leader's predicament in a supreme emergency. Walzer claims that the decision to kill innocents can be justified even though it is morally wrong; the paradox that ensues, however, causes theoretical and practical problems for his theory. The moral tragedy approach does not justify that which should not be justified. Moreover, it recognizes the tragic dilemma facing leaders in a supreme emergency, excusing them from blame if they had no choice. After all, someone must make these decisions, and it is not their fault that the alternatives are all so bad. This does not help us resolve which action is "less bad," but that is the pointeven if one is less bad than the other, neither is "good enough."

\footnotetext{
${ }^{34}$ Igor Primoratz, "Civilian Immunity, Supreme Emergency, and Moral Disaster," The Journal of Ethics 15 (2011): 371-86.
} 


\section{Moral Tragedy and Anti-War Pacifism}

The above discussion has shown that excusing an agent from wrongdoing is distinct from justifying her actions, not only because excuses affect the moral status of the agent while justifications affect the moral status of her actions, but also because an agent who acts wrongly yet is excused from blame is viewed very differently from one who does not act wrongly in the first place. I have defined moral tragedies as situations in which an agent must choose between highly unacceptable options. I have argued that a leader in a supreme emergency that can only be prevented by war can neither justifiably wage war to prevent a disaster nor justifiably fail to prevent that disaster.

The anti-war pacifist position would, of course, be compromised if we were to concede that war could be justifiably fought to prevent some disaster. Such a concession separates those just war theorists who maintain a strong presumption against war from pacifists who argue that war is always unjustified. The moral tragedy solution does not justify war. One might argue, however, that this solution is not sufficiently "antiwar" to be considered a pacifist one. Moreover, one might claim, pacifism should not allow the possibility of excusing from blame those leaders who perform actions in a supreme emergency.

With regard to the agents of war, the first thing to remember is that to excuse the agent is not to excuse the war. One may argue that agents of war should not be excused; rather, they should be held accountable for their actions. And this is correct of most agents in most wars-leaders should only be excused in the most extreme of circumstances, when they have no justifiable options. Moreover, excuses do not provide agents with a reason to wage war. Just how a war is begun, and once begun how it is fought, should also affect how we judge the agents who cause that war. Respecting certain rules of war will not justify the war, but it at least shows the intention, and to some degree the morality, of the agents responsible.

Daniel Statman has argued that the moral tragedy position (as it applies to the just war problem) errs in failing to recognize that an action can be justified as the lesser evil even if it is intrinsically bad:

The point of saying that such a situation represents a real dilemma is to emphasize that the intrinsic evil of the lesser evil option is not erased by the overall judgment that, in the circumstances, it should be preferred over the other (the greater evil) option. An action may be both justified and intrinsically bad. ${ }^{35}$

\footnotetext{
${ }^{35}$ Daniel Statman, "Moral Tragedies, Supreme Emergencies and National-Defence," Journal of Applied Philosophy 23 (2006): 311-22, p. 314. Statman also argues (p. 313) that Orend, Rodin, and Norman agree that one may, on occasion, intentionally kill inno-
} 
In other words, that all the options are wrong does not mean that they are equally wrong, and hence the agent should choose the least bad option.

In responding to Statman's argument we can also address the concern that the moral tragedy pacifist position is not sufficiently "anti-war." His claim is that even if an agent is faced with a morally tragic situation and hence cannot choose a justifiable option, it does not follow that one option cannot be legitimately justified as the lesser evil. Bad actions can be justified, and this does not change when all the options are bad. One might go further, as Statman indeed does, to argue that the agent would act wrongly if she did not choose the lesser evil option. Since the agent has a choice between unjustifiable options, she ought to choose the least bad one, and for that she needs a justification, not an excuse: "The fact that all available options are morally wrong does not mean that they are equally wrong, and when they are not, then the agent is culpable for failing to choose the one that is less wrong." 36

Statman argues that leaders faced with a supreme emergency are not really forced to kill innocents, but rather must make a moral decision to do so. On the other hand, however, the point of the moral tragedy is that although it presents a choice, it is forced or constrained, to the extent that there is no real choice, since neither option is justifiable. If I do not have the option to perform a justified action, then how can it plausibly be said that I should perform a justified action? It cannot, since we cannot reasonably expect persons to perform the impossible. If I can perform a justified action, then I ought to, but if I cannot, then it does not make sense to demand it of me. The "no choice" arises due to a lack of choices to do right.

The moral tragedy solution suggests that in certain cases, all options are tragic and unjustified, even when the consequences of one option are noticeably better than another. For example, imagine a case in which we can only prevent the killing of 1,000,000 innocents by killing 100,000 innocents. Even if we hold that letting 1,000,000 innocents be killed is worse than killing 100,000 innocents, we might nevertheless hold that the situation is a moral tragedy in which there is no morally right course of action to take. The claim is that a good moral system cannot justify the killing of 100,000 innocents to save 1,000,000, since that would not pass whatever threshold is required to justify it. It may also be the case, of course, that failing to prevent the deaths of $1,000,000$ innocents is also unjustifiable. The tragedy is not resolved just because one option is in

cents. This claim is incorrect, although to elaborate would be beyond the scope of this paper (see: Orend, "Just and Lawful Conduct in War," pp. 28-29; Rodin, War and SelfDefense, p. 199; and Norman, Ethics, Killing and War, p. 230).

${ }^{36}$ Statman, "Moral Tragedies," p. 314. 
some sense preferable to another. Neither action can be justified if they are both highly unjustifiable, even if one has "less bad" consequences than the other. In such a scenario, an agent might be compelled to elect one action over another, but would not be justified in doing so.

Viewing the problem in this way suggests that an agent can sometimes be constrained to a morally relevant degree when faced with two or more choices, just as an agent is constrained to a morally relevant degree when she has no choice at all. The morally relevant feature of the tragic supreme emergency that can only be prevented by war is that the agent has no feasible choice but to choose the unjustifiable. She cannot choose an action that is even remotely justifiable; hence we cannot reasonably expect her to do so. And if we cannot expect her to do so, then it does not make sense to demand that she justify her actions in that situation.

Steinhoff argues that a certain action taken in a moral tragedy might be justified as the lesser evil. He claims that although the agent faced with a morally tragic situation cannot do something morally right"whatever one does, it is the wrong thing"-it is nevertheless the case that if one possible action is preferable to the other, then the agent ought to elect that action, and would be justified in doing so: "Since there will not be a modern war without the killing of innocents ... no modern war can ever be just. This does not, however, preclude the possibility that a modern war can be justified - namely as the lesser evil." ${ }^{37}$ This is because "the insight that a war, however noble its aims may be, is always an evil thing ... is more appropriate to the tragedy that is war, and ... can help to progressively restrict the dimensions of its evils." 38

But is it right to condemn war for severely violating the most important rights of many people, but still allow room for its justification? The idea that two actions might be unjustified, and yet one is still morally preferable to the other, is applicable in many cases. Should, for example, a vandal break my letterbox or my front door? Probably the former, since although, all other things equal, both are morally wrong, the latter seems worse. But a supreme emergency is not this type of dilemma. Imagine I am forced into a situation in which something extremely bad will happen unless I do one of two things: kill person A, or kill persons B and C. Consequences are morally relevant, but it is not clear that I would be justified in killing A simply because her death results in one less death overall. It does not seem that preferring that one person die rather than two justifies the killing of that person. A supreme emergency presents an agent with an even worse set of choices. A leader might prefer one action to the other, but she does not have a good moral reason to do so. When

\footnotetext{
${ }^{37}$ Steinhoff, On the Ethics of War and Terrorism, p. 57 (emphasis in original).

${ }^{38}$ Ibid., pp. 57-58.
} 
two options are so unthinkably wrong, I do not believe it is right to say that one is justified simply by virtue of the fact that it is slightly less bad than the other.

The moral tragedy solution to the argument from prevention is a pacifist one in that it does not affect the pacifist's deep commitment to peace and opposition to modern war. It reserves by far the larger part of the moral spectrum for anti-warism. It does not justify war in any way, although it attempts to understand the difficult situations that sometimes motivate the recourse to war. Lying behind this stance, to use Albert Schweitzer's wonderful term, is a "reverence for life." This reverence for life may motivate actions to prevent great suffering, if completely necessary, but that very same reverence means that those actions cannot be morally justified.

In short, since the morally tragic situation is one in which there are no justifiable options, viewing supreme emergencies as morally tragic does not adversely affect the pacifist claim that war is essentially unjustifiable; rather, in fact, it strengthens that claim. In this paper I have framed the supreme emergency problem as a serious issue for any anti-war pacifist, and in response have proposed the moral tragedy solution. Viewing supreme emergencies in which some disaster can only be prevented by war as morally tragic and thus absent of any even justifiable option maintains the pacifist position that war cannot be justified as the lesser evil. By also suggesting that failing to prevent the disaster may also be unjustified, however, this solution recognizes that refusing to wage war is not free from moral difficulty. And finally, allowing those well-intentioned leaders trapped in a supreme emergency to be excused from blame for their actions treats them with the compassion and understanding that such a situation requires. Viewing supreme emergencies as morally tragic, I think, correlates with what we should feel about war in general-war is something to be avoided, at (almost) all costs, and yet we understand that sometimes, at least theoretically, war must be fought to prevent things that are much worse. A theory that can excuse those who choose to wage war or refuse to wage war under very special circumstances, but does not justify their doing so, reflects that sentiment. ${ }^{39}$

Centre for Applied Philosophy and Public Ethics, University of Melbourne nikparkin@gmail.com

\footnotetext{
${ }^{39}$ Many thanks to Andrew Alexandra, Sagar Sanyal, and the anonymous referees for this journal for their valuable comments and suggestions on earlier versions of this paper.
} 
Copyright of Social Theory \& Practice is the property of Florida State University, Dept. of Philosophy and its content may not be copied or emailed to multiple sites or posted to a

listserv without the copyright holder's express written permission. However, users may print, download, or email articles for individual use. 